\title{
Soil Test Based Crop Response Phosphorus Calibration Study on Bread Wheat in Degem District of North Shewa Zone, Oromia
}

\author{
Dejene Getahun*, Abraham Feyisa, Lello Dejene, Dereje Girma \\ Fitche Agricultural Research Center, Oromia, Ethiopia
}

Email address:

dejenegetahun2009@gmail.com (D. Getahun)

${ }^{*}$ Corresponding author

\section{To cite this article:}

Dejene Getahun, Abraham Feyisa, Lello Dejene, Dereje Girma. Soil Test Based Crop Response Phosphorus Calibration Study on Bread Wheat in Degem District of North Shewa Zone, Oromia. International Journal of Economy, Energy and Environment. Vol. 5, No. 1, 2020, pp. 1-5. doi: 10.11648/j.ijeee.20200501.11

Received: March 10, 2020; Accepted: March 20, 2020; Published: April 14, 2020

\begin{abstract}
Soil test based crop response phosphorous calibration study was conducted Degem district on bread Wheat crop during the main cropping season of 2017 -2019 with the objectives to determine Pc and Pf for bread wheat crop, to establish site-specific soil test based phosphorus fertilizer recommendation and to prepare guideline for bread Wheat fertilizer application. RCBD design was used with 3 replication using 4 rates of $\mathrm{N}\left(0,46,92\right.$ and $\left.138 \mathrm{~kg} \mathrm{ha}^{-1}\right)$ and 5 rates of $\mathrm{P}_{2} \mathrm{O}_{5}(0,23$, 46, 69 and $92 \mathrm{Kg} \mathrm{ha}^{-1}$ ) in a factorial combination to determine optimum level of $\mathrm{N}$ - rate for bread wheat crop production. And in the second and third year 6 levels of $\mathrm{P}_{2} \mathrm{O}_{5}\left(0,23,46,69,92\right.$ and $\left.115 \mathrm{Kg} \mathrm{ha}^{-1}\right)$ and $92 \mathrm{~kg} \mathrm{~N}$ ha ${ }^{1}$ of optimum nitrogen rate obtained were applied uniformly for all plots to determine $\mathrm{P}$-critical value $(\mathrm{Pc})$ and P-requirement factor $(\mathrm{Pf})$ for bread Wheat. A total of experimental plot size $5 \mathrm{~m}^{*} 4 \mathrm{~m}\left(20 \mathrm{~m}^{2}\right)$ and Seeds were sown using a seed rate of $150 \mathrm{~kg} \mathrm{ha}^{-1}$ in a plot size of $5 \mathrm{~m} \mathrm{x} 4$ $\mathrm{m}\left(20 \mathrm{~m}^{2}\right)$ by broadcasting. Fertilizers were applied based on the treatments. Grain yield of bread wheat was analyzed using RSoftware. Composite Surface soil samples from $0-20 \mathrm{~cm}$ depth were collected from each experimental plot before planting for laboratory analysis of selected soil chemical properties. Similarly, after 21 days of planting, composite soil samples were taken at (0-20 cm depth) using auger for each treatment and replications separately and the sample were subjected to laboratory analysis using Olsen method to analyze available P content in the soils. The result of the study showed that low to extremely high available P ranged from $4-55.06 \mathrm{ppm}$. The mean maximum grain yield $(3665 \mathrm{~kg} / \mathrm{ha})$ was obtained from the application of $92 \mathrm{~kg} \mathrm{~N} / \mathrm{ha}$ and $92 \mathrm{~kg} \mathrm{P}_{2} \mathrm{O}_{5} /$ ha where as the lowest (1260 kg /ha) was obtained from control (with out fertilizer). Fertilizer combination of $138 \mathrm{~kg} \mathrm{~N} / \mathrm{ha}$ and $92 \mathrm{~kg} \mathrm{P} / \mathrm{ha}$ compared to $92 \mathrm{~kg} \mathrm{~N} /$ ha and $92 \mathrm{~kg} \mathrm{P} /$ ha showed no significant difference on bread wheat grain yield. Therefore, $92 \mathrm{~kg} \mathrm{~N} / \mathrm{ha}$ was selected as $\mathrm{N}$ fertilizer recommended for Degem district. From phosphorous calibration study, P-critical value $(22 \mathrm{ppm})$ and P-requirement factor (5.85) was determined for phosphorus fertilizer recommendation for bread wheat crop production in the area. Therefore, the obtained result has to be verified and the economic benefit must be studied across farmers' fields.
\end{abstract}

Keywords: Calibration, Soil Test, RCBD Design, Economic Benefit

\section{Introduction}

The population of Ethiopia is currently growing at a faster rate and demands an increased proportion of agricultural products. On the other hand, growth in food production is not in equal footings with population pressure (Central Statistical Agency, 2015). Strengthening food production capability of the country by wisely exploiting its existing human and natural resources is critical option to avert the existing situation. But, Ethiopia is one of the sub-Saharan African countries where severe soil nutrient depletion restrains agricultural crop production and economic growth.

The degree of response of soils to applied phosphorus fertilizer is influenced by the soil, amount of available soil phosphorus, amount of clay, organic matter and soil moisture level (Miller et al., 1995). The effect of Pongrain yield was 
highly significant with ageneral increase in yield as the level of $\mathrm{P}_{2} \mathrm{O}_{5}$ increased up to $69 \mathrm{~kg} / \mathrm{ha}$ (Asnakewet al., 1991).

Nitrogen affects crop performance through its ability to determine photosynthetic capacity. Application of nitrogen at onset of stem elongation greatly stimulated leaf area growth, which resulted in significantly greater assimilation capacity, both before and after anthesis (Schulthess and Jutzi, 1997).

However, the annual per-hectare net loss of nutrients is estimated to be at least $40 \mathrm{~kg} \mathrm{~N}, 6.6 \mathrm{~kg} \mathrm{P}$ and $33.2 \mathrm{~kg} \mathrm{~K}$ (Scoones and Toulmin, 1999).

Continuous cropping, high proportions of cereals in the cropping system, and the application of suboptimal levels of mineral fertilizers aggravate the decline in soil fertility (Workneh and Mwangi, 1992). Hence, identification of proper fertilizer mix is beneficial at the macroeconomic level by improving the efficiency of fertilizer procurement and resource allocation.

Therefore, profitable crop production requires adequate levels of phosphorus $(\mathrm{P})$ and other nutrients. For this careful planning is required because of volatile grain and fertilizer prices. So, sound soil test calibration is essential for successful fertilizer program and crop production. It is essential that the results of soil tests could be calibrated or correlated against crop responses from applications of plant nutrients in question as it is the ultimate measure of a fertilization program.

An accurate soil test interpretation requires knowledge of the relationship between the amount of a nutrient extracted by a given soil test and the amount of plant nutrients that should be added to achieve optimum yield for each crop (Sonon and Zhang, 2008). Hence, calibration is a vital tool to attain the objective while calibrations are specific for each crop type and they may also differ by soil type, climate, and the crop variety. That means, fertilizer recommendations on soil test basis for economic crop production should be both location and situation specific and can be modified with changes in soil test value as well as input output ratios. Soil test based fertilizer recommendation plays a vital role in ensuring balanced nutrition to crops. Therefore, fertilizer application schedules should be based on the magnitude of crop response to applied nutrients at different soil fertility levels (Santhietal. 2002).

As in all other regions of the country, fertilizer recommendations in Degem district is also not based on soil test results.

Therefore, this study was initiated with the objectives to determine P-critical and P-requirement factor (pf) and to establish site-specific soil test based phosphorus fertilizer rate recommendation for bread wheat production on major soil of the districts.

\section{Materials and Method}

\subsection{Site Description}

The trial was conducted in Degem districts of North Shewa Zone, Oromia. The District is found in the North-
Western direction at a distance of $123 \mathrm{~km}$ from Addis Ababa capital city of Ethiopia and $10 \mathrm{~km}$ from Fitche, capital city of North Shewa, Oromia. It has an astronomical location which extends from $38^{\circ} 25^{\prime} 0^{\prime}$ ' E-38 $45^{\circ} 00 \mathrm{E}$ and $09^{\circ} 03^{\prime}{ }^{\prime} 0{ }^{\prime} 0 \mathrm{~N}$ $10^{\circ} 30^{\prime} 0^{\prime \prime} \mathrm{N}$ longitude and latitude respectively.

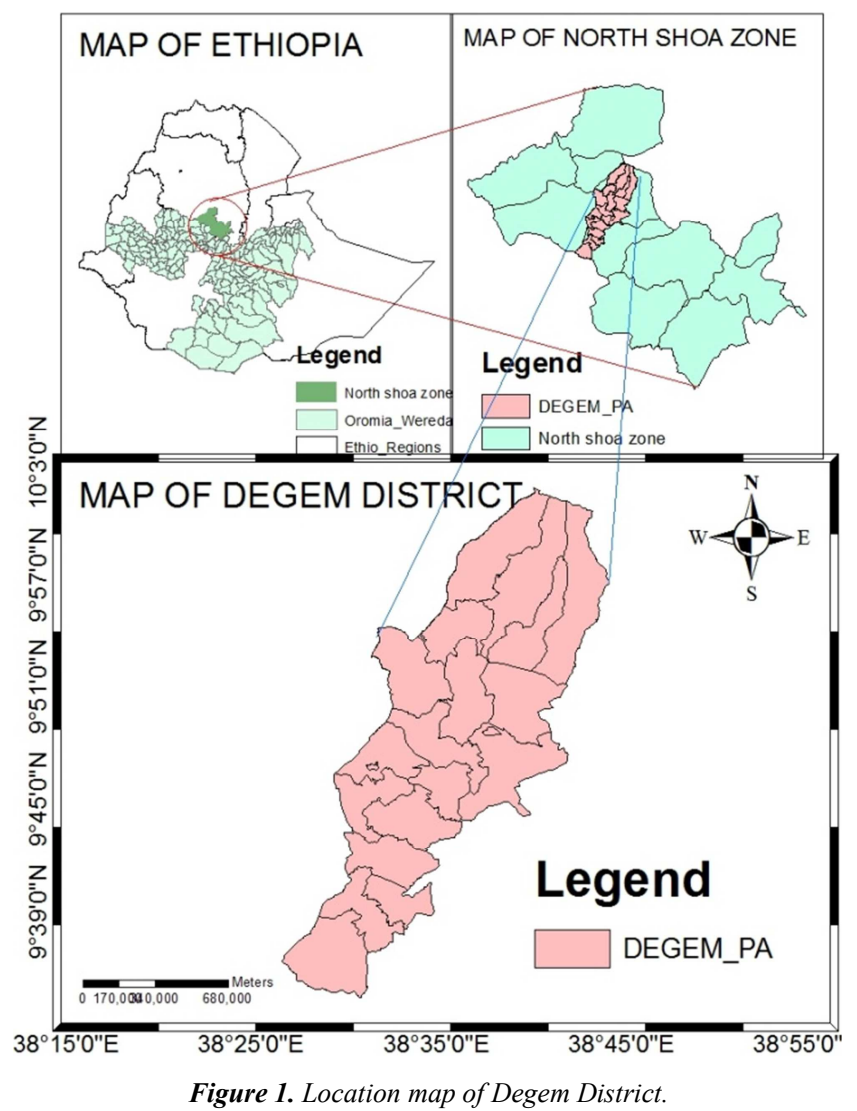

\subsection{Experimental Design, Treatment and Procedure}

On farm study was conducted in the district during the main cropping seasons (2017 to 2019) to determine Optimum level of Nitrogen fertilizer, P-critical value and Prequirement factor for P-fertilizer recommendation of bread wheat for the district. The treatment of the experiment were factorial combination of 4 rates of $\mathrm{N}(0,46,92$ and $138 \mathrm{~kg}$ $\left.\mathrm{ha}^{-1}\right)$ and 5 levels of $\mathrm{P}_{2} \mathrm{O}_{5}\left(0,23,46,69\right.$ and $\left.92 \mathrm{Kg} \mathrm{ha}^{-1}\right)$ in the first year to determine optimum level of $\mathrm{N}$ - rate for bread wheat production in the district (Table 1).

Table 1. Treatment Description.

\begin{tabular}{llll}
\hline $\begin{array}{l}\text { N-level1 } \\
\text { Treatment }\end{array}$ & $\begin{array}{l}\text { N-level2 } \\
\text { Treatment }\end{array}$ & $\begin{array}{l}\text { N-level3 } \\
\text { Treatment }\end{array}$ & $\begin{array}{l}\text { N-level 4 } \\
\text { Treatment }\end{array}$ \\
\hline$(\mathrm{T} 1-\mathrm{T} 5)$ & $(\mathrm{T} 6-\mathrm{T} 10)$ & $(\mathrm{T} 11-\mathrm{T} 15)$ & $(\mathrm{T} 16-\mathrm{T} 20)$ \\
$\mathrm{N}: \mathrm{P}_{2} \mathrm{O}_{5} \mathrm{~kg} / \mathrm{ha}$ & $\mathrm{N}: \mathrm{P}_{2} \mathrm{O}_{5} \mathrm{~kg} / \mathrm{ha}$ & $\mathrm{N}: \mathrm{P}_{2} \mathrm{O}_{5} \mathrm{~kg} / \mathrm{ha}$ & $\mathrm{N}: \mathrm{P}_{2} \mathrm{O}_{5} \mathrm{~kg} / \mathrm{ha}$ \\
$\mathrm{T} 1(0: 0)$ & $\mathrm{T} 6(46: 0)$ & $\mathrm{T} 11(92: 0)$ & $\mathrm{T} 16(138: 0)$ \\
$\mathrm{T} 2(0: 23)$ & $\mathrm{T} 7(46: 23)$ & $\mathrm{T} 12(92: 23)$ & $\mathrm{T} 17(138: 23)$ \\
$\mathrm{T} 3(0: 46)$ & $\mathrm{T} 8(46: 46)$ & $\mathrm{T} 13(92: 46)$ & $\mathrm{T} 18(138: 46)$ \\
$\mathrm{T} 4(0: 69)$ & $\mathrm{T} 9(46: 69)$ & $\mathrm{T} 14(92: 69)$ & $\mathrm{T} 19(138: 69)$ \\
$\mathrm{T} 5(0: 92)$ & $\mathrm{T} 10(46: 92)$ & $\mathrm{T} 15(92: 92)$ & $\mathrm{T} 20(138: 92)$ \\
\hline
\end{tabular}

Gross plot size: $3 \mathrm{~m} \times 4 \mathrm{~m}$.

Harvested area: $2 \mathrm{~m} \times 2 \mathrm{~m}$. 
Single factor of six (6) level of $\mathrm{P}_{2} \mathrm{O}_{5}(0,23,46,69,92$ and $\left.115 \mathrm{Kg} \mathrm{ha}^{-1}\right)$ and $92 \mathrm{~kg} \mathrm{~N} / \mathrm{ha}$ treatments combinations were used in the P-calibration experiment in second and third year to determine P-critical value and p-requirement factor. Land was prepared using oxen plow. Bread wheat seed and fertilizers were broadcast. The trial was conducted in completely randomized block design (RCBD) in three replications on net plot size $5 \mathrm{~m} * 4 \mathrm{~m}=20 \mathrm{~m}^{2}$.

Recommended and sufficient amount of nitrogen $(92 \mathrm{~kg} / \mathrm{ha})$ was applied uniformly for all plots. Improved variety of bread wheat Danda'a was used as a test crop. Seeds were sown using a seed rate of $150 \mathrm{~kg}$ ha- 1 in a plot size of $5 \mathrm{~m} \mathrm{x}$ $4 \mathrm{~m}\left(20 \mathrm{~m}^{2}\right)$ by broadcasting. Fertilizers were applied based on the treatments.

\subsection{Soil Sampling and Analysis}

Out of the 41 farmers' field analyzed, twenty farmers' fields (eight and twelve in $1^{\text {st }}$ and $2^{\text {nd }}$ year respectively) were selected those that vary with respect to soil test value, over the whole range from very low to very high (low, medium and high $\mathrm{P}$ soils) as test sites.

Similarly, after 21 days of planting, composite soil samples were taken at $20 \mathrm{~cm}$ depth using auger for each treatment and replications separately and the sample were subjected to laboratory analysis using Olsen Method to analyze available $\mathrm{P}$ content in the soils, which enables to determine $\mathrm{P}$ critical level and P-requirement factor.

\subsection{Determination of Phosphorus Critical Level and P-requirement Factor}

\subsubsection{Determination of P-requirement Factor (Pf)}

Based on $\mathrm{P}$ laboratory analysis result of post planting soil samples (available $P$ values in samples collected from unfertilized and fertilized plots) data P-requirement factor

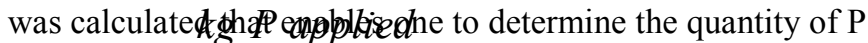
required per hectare to rise the soil test by $1 \mathrm{mg} / \mathrm{kg}$ which is equal to $\mathrm{Pf}=$ and to determine the amount of fertilizers required per hectare to bring the level of available $P$ above the critical level.

Phosphorus requirement factor $(\mathrm{Pf})$ was calculated using available $\mathrm{P}$ values in soil sample collected and analyzed from each unfertilized and fertilized experimental plot, after that the relation between each fertilizer rate and averaged corresponding soil test $\mathrm{P}$ value for each fertilizer rate was calculated.

\subsubsection{Determination of Phosphorus Critical Level (Pc)}

For determination of P-critical value, the Cate-Nelson diagram method (Nelson and Anderson, 1977) was used, where soil $\mathrm{P}$ values were put on the $\mathrm{X}$ - axis and relative yield values on the $\mathrm{Y}$-axis, and scatter points were divided into two populations. This was achieved by overlay of a clear plastic sheet having a pair of perpendicular lines drawn on it to produce four quadrants. The overlay was the positioned on the graph in such a way that the maximum number of points fell in the positive quadrants while the lowest number fell in the negative quadrants. The vertical line defines the responsive and non -responsive ranges while the optimum is indicated by the point where the vertical line crosses the $\mathrm{x}$ axis. The two intersecting lines were then drawn lightly on the graph. The point where the vertical lines cross the $\mathrm{X}$-axis is defined as 'critical soil test level'. Data from 20 sites for each crop and all treatment with their replications were used for such analysis.

\subsection{Economic Analysis}

Economic analysis was undertaken to investigate the economic feasibility of the treatments. Partial budget analysis was done to identify economical feasibility among different Nitrogen level fertilizer rate for bread wheat crop production. The average open market price (Birr/ kg) of wheat, price of Urea $(\mathrm{N})$ and DAP (P) fertilizers were used for analysis. For a treatment to be considered a worthwhile option to farmer, the minimum acceptable rate of return (MARR) should be $100 \%$ (CIMMT, 1988), which is suggested to be realistic. This enables to make recommendations from marginal analysis.

\subsection{Agronomic Data Collection}

During the different growth stages of the crop, all necessary field management practices were carried out as per the practice followed by the farming community.

Agronomic data were collected on planting date, maturity date, plant height, biomass and grain yield.

All Agronomic and soil data were properly managed using EXCEL computer software. Grain yield were analyzed using R software program.

\section{Result and Discussion}

\subsection{Soil Available Phosphorous}

Available Phosphorous (Olsen method) collected before planting was ranged from $4 \mathrm{ppm}$ to $55.06 \mathrm{ppm}$. The available $\mathrm{P}$ content of the soil was ranged from low to extremely high (Olsen et al., 1954).

Table 2. Initial available soil phosphorous status before planting in Degem district.

\begin{tabular}{ll}
\hline Site & Available $\mathbf{p}(\mathbf{p p m})$ \\
\hline Site 1 & 4.0 \\
Site 2 & 6.6 \\
Site 3 & 6.6 \\
Site 4 & 10.6 \\
Site 5 & 8.6 \\
Site 6 & 7.3 \\
Site 7 & 18.0 \\
Site 8 & 6.0 \\
Site 9 & 14.87 \\
Site 10 & 14.58 \\
Site 11 & 46.07 \\
Site 12 & 9.54 \\
Site 13 & 36.29 \\
Site 14 & 22.01 \\
Site 15 & 46.77 \\
Site 16 & 21.25 \\
\hline
\end{tabular}




\begin{tabular}{ll}
\hline Site & Available p (ppm) \\
\hline Site 17 & 15.16 \\
Site 18 & 55.06 \\
Site 19 & 38.34 \\
Site 20 & 33.10 \\
Average & 21.037 \\
\hline
\end{tabular}

\subsection{Nitrogen Fertilizer Determination}

The main effects of both $\mathrm{N}$ and $\mathrm{P}$ fertilizer were highly significant $(\mathrm{p}<0.01)$ and the interaction effects were significant $(\mathrm{p}<0.05)$ for some grain yield of bread wheat. Bread wheat experimental data analysis result indicated that, all treatments significantly produce mean grain yield as compared to the control except treatment $3\left(0 \mathrm{~N}: 46 \mathrm{P}_{2} \mathrm{O}_{5}\right)$.
Accordingly, the mean maximum grain yield $(3665 \mathrm{~kg} / \mathrm{ha})$ was obtained from the application of $92 \mathrm{~kg} \mathrm{~N} / \mathrm{ha}$ and $92 \mathrm{~kg}$ $\mathrm{P}_{2} \mathrm{O}_{5} /$ ha where as the lowest $(1260 \mathrm{~kg} / \mathrm{ha})$ was obtained from control (Table 3). This result signifies that the existence of positive interaction of $\mathrm{P}$ and $\mathrm{N}$ fertilizers for the production of bread wheat, and the responsiveness to the application of high level fertilizer phosphorus. Similarly, previous research output reported by Desta (1978), Mesfin (1980) and Asnake and Tekalign (1991), also supports this experimental result. However, fertilizer combination of $138 \mathrm{~kg} \mathrm{~N} / \mathrm{ha}$ and $92 \mathrm{~kg} \mathrm{P}$ /ha compared to $92 \mathrm{~kg} \mathrm{~N} / \mathrm{ha}$ and $92 \mathrm{~kg} \mathrm{P} /$ ha showed no significant difference on bread wheat grain yield. Therefore, $92 \mathrm{~kg} \mathrm{~N} /$ ha was selected as $\mathrm{N}$ fertilizer recommended for the area.

Table 3. Interaction effect of NP on bread wheat grain yield $(\mathrm{kg} / \mathrm{ha}$ ) in Degem district in 2017 cropping season.

\begin{tabular}{|c|c|c|c|c|c|c|}
\hline \multirow{2}{*}{ N-level } & \multicolumn{5}{|l|}{$\mathrm{P}_{2} \mathrm{O}_{5}$} & \multirow{2}{*}{ Mean } \\
\hline & 0 & 23 & 46 & 69 & 92 & \\
\hline 0 & $1260.00^{\mathrm{i}}$ & $1605.00^{\mathrm{gh}}$ & $1441.67^{\mathrm{hi}}$ & $1705.00^{\text {gh }}$ & $1858.33^{\mathrm{g}}$ & 1574 \\
\hline 46 & $2141.67 \mathrm{f}$ & $2266.67^{f}$ & $2250.00^{f}$ & $2383.33^{f}$ & $2366.67^{f}$ & 2281.67 \\
\hline 92 & $2730.00 \mathrm{e}$ & $3046.67^{d}$ & $3071.67^{d}$ & $3806.80^{\mathrm{a}}$ & $3665.00^{\mathrm{ab}}$ & 3264.03 \\
\hline 138 & $3083.33^{d}$ & $3278.33^{\mathrm{cd}}$ & $3420.00^{\mathrm{bc}}$ & $3388.333^{c}$ & $3541.67^{\mathrm{bc}}$ & 3342.33 \\
\hline $\operatorname{LSD}(5 \%)$ & 263.95 & & & & & \\
\hline CV $(\%)$ & 14.04 & & & & & \\
\hline
\end{tabular}

Note: The mean with the same letters are not significantly different at $\mathrm{P}<0.05$.

\subsection{Phosphorus Critical Value and P-requirement Factor}

The result of the study revealed that P-critical value (22 ppm) (figure 2) and P-requirement factor 5.85 (table 4) were determined for phosphorus fertilizer recommended for the area.

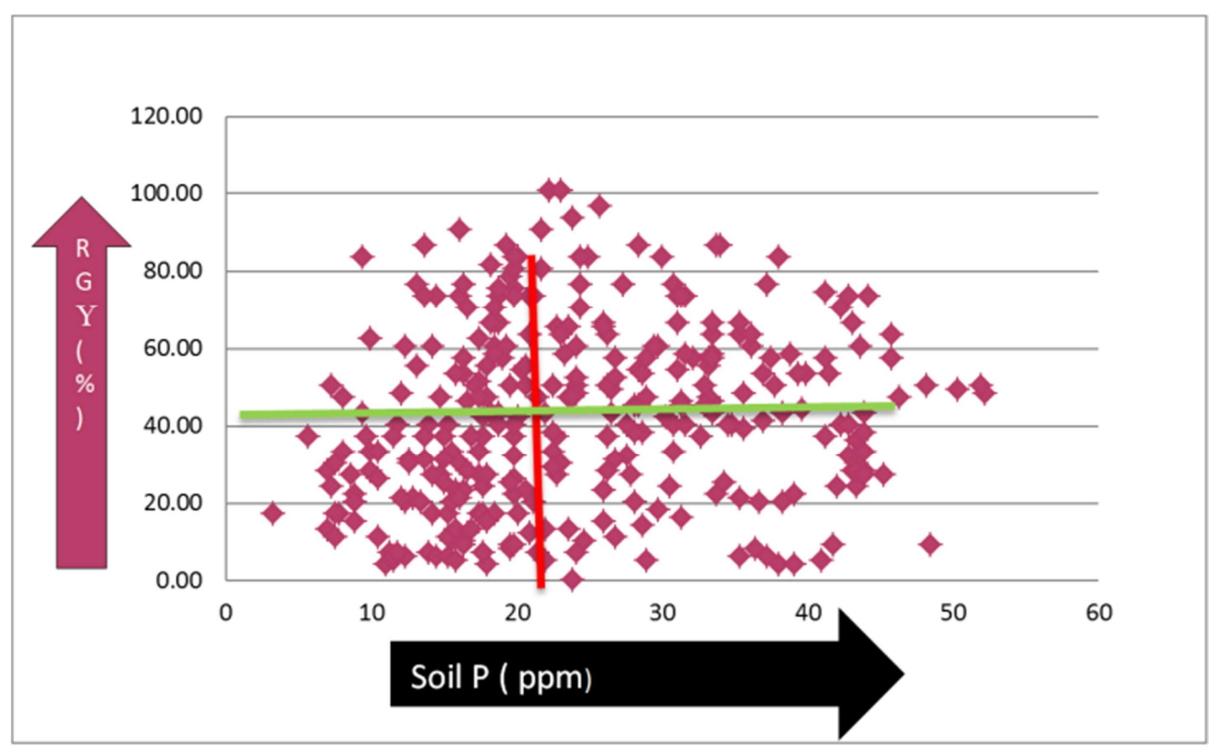

Figure 2. Critical P-concentration as determined by Cate-Nilson method.

Table 4. Phosphorus Requirement factor for Bread wheat for Degem District.

\begin{tabular}{llll}
\hline P-fertilizer applied & Olsen P $(\mathbf{p p m})$ Mean & P level increase over thecontrol (Olsen method) & P-requirementfactor (pf) \\
\hline 0 & 20.71 & - & - \\
10 & 24.61 & 3.9 & 2.56 \\
20 & 24.83 & 4.12 & 4.85 \\
30 & 24.96 & 4.25 & 7.06 \\
40 & 25.99 & 5.28 & 7.58 \\
50 & 27.66 & 6.95 & 7.20 \\
Mean5.85 & & & \\
\hline
\end{tabular}


Table 5. Marginal rate of return analysis.

\begin{tabular}{llllllllll}
\hline \multirow{2}{*}{ SN } & $\begin{array}{l}\text { Fertilizer } \\
\text { rate }\end{array}$ & Variable Input (Kg/ha) & $\begin{array}{l}\text { Unit price } \\
\text { (ETB) }\end{array}$ & TVC & $\begin{array}{l}\text { Output } \\
\text { (Kg/ha) }\end{array}$ & $\begin{array}{l}\text { Unit price } \\
\text { (ETB) }\end{array}$ & $\begin{array}{l}\text { Gross } \\
\text { Income }\end{array}$ & $\begin{array}{l}\text { Net } \\
\text { Income }\end{array}$ & $\begin{array}{l}\text { MRR } \\
\text { (\%) }\end{array}$ \\
\hline 1 & N-level 1 & 0 & 10.4 & 0 & 1574 & 10 & 15740 & 15740 \\
2 & N-level 2 & 100 & 10.4 & 1040 & 2281.667 & 10 & 22816.67 & 21776.67 & 580.45 \\
3 & N-level 3 & 200 & 10.4 & 2080 & 3264.027 & 10 & 32640.27 & 30560.27 & 712.51 \\
4 & N-level 4 & 300 & 10.4 & 3120 & 3342.333 & 10 & 33423.33 & 30303.33 & 466.77 \\
\hline
\end{tabular}

Economic Analysis for Optimum Nitrogen determination on Bread Wheatproduction in Degem District in 2017

The partial budget presented in (table 5) indicated that the least total variable cost (TVC) was recorded by control treatment, while the highest net income was obtained from $\mathrm{N}$ level 3 .

The Marginal rate of return were found to be range from $466.77 \%$ in $\mathrm{N}$ level 4 to $712.51 \%$ in $\mathrm{N}$ level $3(92 \mathrm{~kg} \mathrm{~N} /$ ha and $92 \mathrm{~kg} \mathrm{P} / \mathrm{ha}$ ) as indicated in (Table 5).

\section{Conclusion and Recommendation}

In Ethiopia, chemical fertilizers are as one of the most important inputs for maintaining soil fertility and maximizing agricultural production and productivity of the country. Crop production can be profitable if and only if adequate and balanced levels of phosphorus ( $p$ ) and other nutrient are used. Sound soil test calibration is essential for successful fertilizer program and crop production.

Phosphorus calibration study has been conducted on bread wheat for two years (2017-2019 growing season) at Degemdistrict.

Accordingly, Optimum nitrogen rate $(92 \mathrm{~kg} \mathrm{~N} / \mathrm{ha})$, critical $\mathrm{P}(\mathrm{Pc})$ concentrations $(22 \mathrm{ppm})$ and $\mathrm{P}(\mathrm{Pf})$ requirement factors (5.85) for bread wheat have been determined, at Degem bread wheat growing area.

Farther verification of the result on farmers field could be a prerequisite before disseminating the technology to the user.

\section{Acknowledgements}

First of all, we thank our God who enables us, in all down and ups, to perform our research activity properly. Secondly, the authors would like to thank Oromia Agricultural Research Institute for financial support and Fitche Agricultural Research Center for providing all the necessary facilities required for the research. At last but not at least, our special thank also forwarded to all staff members, especially to Laboratory analysis team for their support and unreserved effort to provide reliable samples analysis data.

\section{References}

[1] Asnakew Wolde-ab, Tekalign Mamo, Mengesha Bekele and Tefera Ajema. 1991. Soil Fertility Management ofwheat in Ethiopia. pp. 112-144. In: HailuGebre Mariam, Tanner, D. G and Mengestu Hulluka (ed). Wheat Research in Ethiopia historical perspective. IAR/CIMMYT, Addis Ababaz.

[2] CIMMYT, 1988. From Agronomic data to farmer Recommendation: An Economic Training Manual. Completely revised edition, Mexico, DF.

[3] CSA (Central Statistical Authority), 2015. Agricultural Sample Survey 2014/2015 vol. 1. Report On area and production for major crops (private peasant holding meher season) statistical Bulletin 278, Addis Ababa, Ethiopia.

[4] Olsen, S. R. Cole, Watanable, F. S. and Dean, L. A. (1954) Estimation of available phosphorus in soils by extraction with sodium bicarbonate. Circ. U.S. Dep. Agric. 939.

[5] Penning De Veris and P. Nyamudeza (eds.). The sustainable management of Vertisols. Proceedings of the $20^{\text {th }}$ International Board for Soil Research and Management (IBSRAM).

[6] Prasad, R and J. Power. 1997. Soil fertility Management for sustainable Agriculture. Lewis publishers, Bocan Raton, New Work.

[7] Santhi R, Natesan R, and G. Seh'akumari, 2002. Soil test based fertilizer recommendation under IPNS for aggregatum onion in Inceptisols of Tamil Nadu. Department of Soil Science and Agricultural Chemistry. Tamil jadu Agricultural University. Coimhatore Ml 003. India. Agrupedolo R. V, 12: 141-147.

[8] Schulthess, Urs. Boy Feil and S. C. Jutzi, 1997. Yield independent variation in grain nitrogen and phosphorus concentration among Ethiopian wheat. Agronomy, 89 (3): 497-506.

[9] Scoones and C. Toulmin (eds), 1999. Polices for Soil fertility Management in Africa. IIED/DFID, London.

[10] Seyfu Ketema, 1993. "Breeding, Genetic resources, Agronomy, Utilization and role of tef in Ethiopian Agriculture", Ethiopian Institute of Geological Surveys, Ministry of Mines and Energy, Addis Ababa, Ethiopia. 